\title{
ANALISIS CITRA SATELIT LANDSAT 8 DAN DEMNAS UNTUK IDENTIFIKASI PROSPEK PANAS BUMI DI KABUPATEN ACEH TENGAH, PROVINSI ACEH
}

\section{LANDSAT 8 AND DEMNAS IMAGES ANALYSES TO IDENTIFY GEOTHERMAL PROSPECT IN CENTRAL ACEH REGENCY, ACEH PROVINCE}

\author{
Husin Setia Nugraha, Lano Adhitya Permana, dan Sukaesih \\ Pusat Sumber Daya Mineral Batubara dan Panas Bumi \\ husin_setia_n@yahoo.com
}

\begin{abstract}
ABSTRAK
Gabungan beberapa analisis pada citra satelit Landsat dan Digital Elevation Mode/ Nasional (DEMNAS) dapat dipergunakan untuk mengidentifikasi indikasi area prospek panas bumi. Analisis dilakukan di Kabupaten Aceh Tengah yang diawali dari informasi keberadaan mata air panas pada peta geologi regional lembar Takengon. Metoda penginderaan jauh seperti metoda Fault and Fracture Density (FFD) dan interpretasi circular feature diterapkan pada citra DEMNAS. Sedangkan metoda Land Surface Temperature (LST) dan Direct Principal Component Analysis (DPCA) diterapkan pada citra Landsat 8. Kenampakan circular feature, anomali LST dan indikator adanya mineral ubahan bersuhu tinggi, dapat digunakan untuk memperkirakan keberadaan sumber panas. Sedangkan penerapan FFD digunakan untuk memperoleh indikator adanya zona dengan permeabilitas tinggi yang diperlukan dalam sistem panas bumi.
\end{abstract}

Hasil penelitian menunjukkan bahwa indikasi sumber panas diperkirakan berada pada komplek vulkanik Gunung Telege yang berada di daerah Kecamatan Atu Lintang. Hal ini diperlihatkan dengan adanya circular feature dan anomali LST yang terdapat di daerah tersebut. Penerapan metoda FFD mengindikasikan adanya zona outflow yang berada di sekitar manifestasi mata air panas yang terletak di sebelah barat laut Gunung Telege. Sedangkan dari hasil penerapan metoda DPCA sulit untuk diinterpretasi dikarenakan belum adanya pemisahan yang tegas antara indikator zona argilik lanjut dan zona propilitik dari hasil DPCA tersebut. Hal ini kemungkinan disebabkan adanya nilai pencampuran antar beberapa indikasi mineral dalam satu piksel yang sama. Secara umum, penggunaan metoda penginderaan jauh di Kabupaten Aceh Tengah dapat membantu untuk memberikan petunjuk awal adanya kemungkinan sistem panas bumi di daerah tersebut.

Kata kunci: Fault and Fracture Density (FFD), Land Surface Temperature (LST), Direct Principal Component Analysis (DPCA), Gunung Telege

\section{ABSTRACT}

Combined analyses of Landsat satellite image and Digital Elevation Model Nasional (DEMNAS) are used to identify geothermal prospect areas. The analyses are applied in Aceh Tengah Regency because the information of springs exists in the regional geological map of Takengon. Two methods are applied to DEMNAS, namely the FFD method and circular features visual interpretation. Land Surface Temperature (LST) and Direct Principal Component Analysis (DPCA) methods are employed on Landsat 8 image. The appearance of circular features, anomalies of LST, and the existence of high-temperature mineral indicators are used to predict heat source indication. In addition, the FFD method is employed to indicate high permeability zones.

The research shows that heat source indication is predicted at Mt. Telege Volcanic Complex within the District of Atu Lintang. The heat source is indicated by circular features appearance 
and LST anomalies within the area. Furthermore, the FFD method reveals an outflow zone near the hot spring of the northern part of Mt. Telege. In addition, the implementation of the DPCA method could not clearly separate between advanced argillic dan propylitic zones from their mineral indication values. It is due to mixing values among several mineral indicator values within the same pixel. In general, the application of the remote sensing method in Aceh Tengah Regency could help to indicate an early possibility of geothermal system exist within the area.

Keywords: Fault and Fracture Density (FFD), Land Surface Temperature (LST), Direct Principal Component Analysis (DPCA), Mt. Telege

\section{PENDAHULUAN}

Penggunaan metoda penginderaan jauh (remote sensing) untuk eksplorasi panas bumi dari berbagai penelitian, telah dirangkum secara komprehensif oleh van der Meer et al. (2014). Metoda ini dipergunakan untuk mendeteksi keberadaan potensi panas bumi baik langsung maupun tidak langsung dari indikasi keberadaan mineral terubah, anomali suhu dan heatflux hingga anomali kenampakan vegetasi dan perubahan muka bumi.

Bukti langsung keberadaan prospek panas bumi berdasarkan metoda penginderaan jauh dapat dilihat dari keberadaan fitur di permukaan dan adanya keberadaan zona ubahan (alteration zone). Fitur di permukaaan dapat berupa adanya penampakan struktur kaldera, mata air panas, steaming ground dan fumarol yang disertai adanya struktur geologi berupa kelurusan atau sesar. Keberadaan mineral ubahan yang dideteksi melalui metoda penginderaan jauh terkadang terlihat dipermukaan. Keberadaan zona ubahan tersebut berupa nilai anomali bilangan digital (Digital Number) pada area tertentu. Zona ubahan tersebut merupakan indikasi adanya interaksi fluida panas bumi dengan batuan. Dengan demikian, keberadaan zona ubahan dapat menjadi indikator keberadaan sistem panas bumi (van der Meer et al., 2014).

Lebih lanjut van der Meer et al. (2014) menjelaskan bahwa secara tidak langsung, indikasi keberadaan sistem panas bumi dapat diketahui melalui adanya anomali suhu permukaan dan perubahan atau deformasi permukaan bumi. Anomali suhu permukaan dapat menunjukan adanya aktivitas heatflux yang dapat diindikasikan sebagai sumber panas.

Adanya deformasi permukaan bumi dapat menjadi indikasi adanya aktivitas sistem panas bumi, seperti pada studi deformasi permukaan dengan menggunakan Interferometric Synthetic-Aperture Radar (InSAR) yang bertujuan untuk memonitor penurunan muka tanah (subsidence) dan deformasi permukaan. Berdasarkan hal tersebut, studi penginderaan jauh yang dilakukan pada tahap eksploitasi dapat digunakan untuk melihat subsidence, sebagai akibat adanya ekstraksi fluida panas bumi dan perubahan tekanan, seperti penelitianyang telah dilakukan oleh Carnec dan Fabriol (1999) dan Fialko dan Simon (2000). Sedangkan studi deformasi pada tahap eksplorasi, bertujuan untuk mendeteksi adanya depresi permukaan karena adanya aktivitas panas bumi di lapisan sub-glacial seperti yang dilakukan di Vatnajokull, Islandia (Jónsson et al., 1998).

Analisis struktur bertujuan untuk melihat hubungan antara struktur geologi dengan sistem panas bumi dan kondisi hidrogeologi, sehingga dapat diketahui peranan dari struktur geologi sebagai media untuk sirkulasi fluida panas bumi (Giordano et al., 2013). Secara umum, penggunaan metoda penginderaan jauh yang digunakan untuk eksplorasi panas bumi, baik berupa analisis langsung atau tidak langsung, dapat menggunakan citra Digital Elevation Model (DEM) dari hasil akusisi satelit atau LiDAR. 
Penelitian ini dilakukan untuk mengetahui keberadaaan daerah prospek sistem panas bumi di Kabupaten Aceh Tengah melalui analisis data sekunder seperti kemunculan mata air panas dan penerapan metoda penginderaan jauh. Lokasi penelitian sebagian besar terletak di Kabupaten Aceh Tengah yang memiliki luas sekitar 303.726 hektar dengan fokus daerah penelitian berada di Kecamatan Atu Lintang, Kabupaten Aceh Tengah (Gambar 1)

\section{METODOLOGI}

Metodologi yang digunakan pada penelitian di Kabupaten Aceh Tengah melalui penerapan metoda penginderaan jauh seperti yang tampak pada gambar 2 . Metoda penelitian ini membutuhkan adanya interpretasi kelurusan, circular feature dan anomali suhu permukaan serta keterdapatan mineral ubahan. Metoda Penerapan penginderaan jauh di Kabupaten Aceh, merupakan modifikasi dari metoda yang diterapkan oleh Hakim et al. (2017) pada lokasi Gunung Bur Ni Telong yang berada di sebelah utara daerah penelitian.

Interpretasi kelurusan dan circular feature menggunakan citra DEMNAS yang telah dikonversi menjadi citra hillshade dengan berbagai derajat azimuth dengan kemiringan horizon cahaya pada $45^{\circ}$ dari bidang datar. Penelitian ini menggunakan delapan citra hillshade dengan azimuth yang berbeda yaitu $0^{\circ}, 45^{\circ}, 90^{\circ}, 135^{\circ}, 180^{\circ}$, $225^{\circ}, 270^{\circ}$, dan $315^{\circ}$.

Hillshade adalah metoda yang digunakan untuk mempresentasikan gambaran relief sebuah wilayah dari citra DEM yang masih dalam format 2-D (2 Dimensi) dengan cara memberikan kesan 3-D (3 Dimensi) pada citra tersebut (ESRI, 2006).

Interpretasi untuk anomali suhu permukaan dan kandungan mineral di permukaan pada daerah penelitian menggunakan metoda perhitungan Land Surface Temperature (LST) dan aplikasi modifikasi Principal Component Analysis (PCA) untuk dua komponen atau yang disebut Direct Principal Component Analysis (DPCA) yang diimplementasikan pada citra Landsat 8 (Salamba et al., 2019).

Selanjutnya, hasil interpretasi dan analisis anomali yang berupa peta, akan digabungkan dengan peta geologi dan manifestasi permukaan yang ada. Interpretasi dari gabungan peta-peta tersebut akan menghasilkan perkiraan daerah yang terkait dengan keberadaan sistem panas bumi seperti adanya sumber panas (heatsource), outflow dan reservoir.

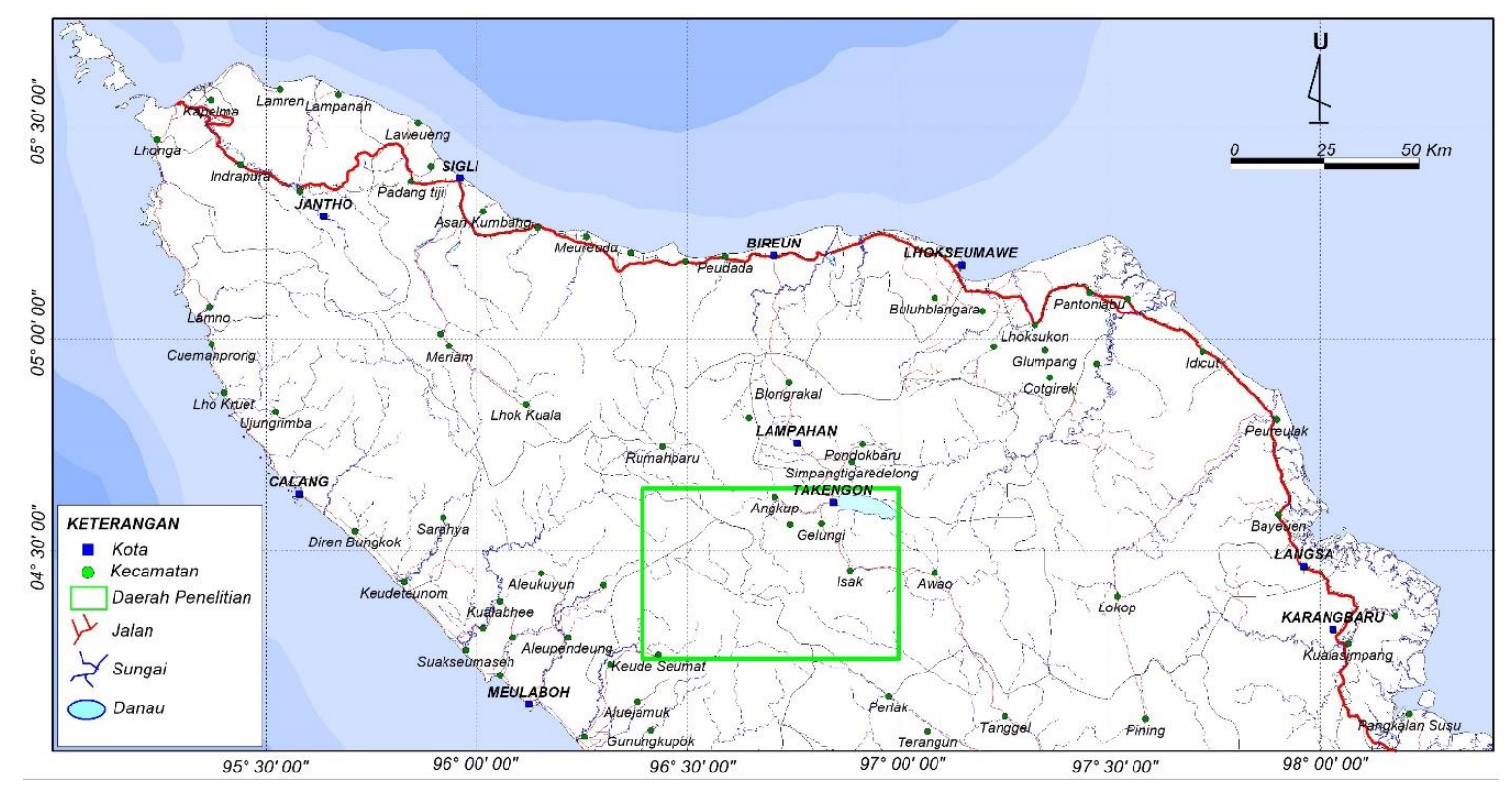

Gambar 1.Peta Lokasi Studi di Kabupaten AcehTengah 
Keberadaan sumber panas yang terdapat di daerah penelitian akan diwakili oleh adanya circular feature dan anomali suhu permukaan serta keberadaan mineral indikator suhu tinggi. Untuk area reservoir biasanya akan di representasikan dengan area yang memiliki kerapatan kelurusan yang tinggi (Hakim et al., 2017 dan Nugraha et al., 2018).

Metoda Fault and Fracture Density (FFD) Metoda pertama yang diterapkan dalam penelitian ini, yaitu metoda FFD. Data DEMNAS dari Badan Informasi Geospasial (BIG) digunakan untuk membuat peta densitas kelurusan di daerah Kabupaten Aceh Tengah.

Prinsip yang digunakan dalam pembuatan peta densitas kelurusan dengan metoda FFD, yaitu mengasumsikan kelurusan sebagai sesar dan rekahan yang merupakan bidang lemah untuk jalur pergerakan fluida panas. Algoritma metoda FFD dari Hakim et al. (2017) akan diterapkan pada penelitian ini.

Data DEMNAS yang telah disesuaikan dengan daerah penelitian akan dikonversi ke dalam bentuk hillshade dengan sudut azimuth $0^{\circ}, 45^{\circ}, 90^{\circ}, 135^{\circ}, 180^{\circ}, 225^{\circ}, 270^{\circ}$, dan $315^{\circ}$. Dalam hal ini, Data DEMNAS tersebut tidak perlu dilakukan koreksi geometrik dan radiometrik. Kelurusan yang telah diperoleh dari data DEMNAS, kemudian dikelompokkan pada grid dengan ukuran $2 \mathrm{~km} \times 2 \mathrm{~km}$ untuk menghasilkan kontur kerapatan kelurusan. Pada tahap studi awal ini dipilih besaran $2 \mathrm{~km}$ dengan tujuan mendapatkan kerapatan struktur regional sebagai informasi tambahan untuk interpretasi sistem panas bumi.

Selanjutnya akan terlihat daerah-daerah yang memiliki kerapatan tinggi dan rendah. Area dengan kerapatan tinggi bisa dianggap mewakili daerah prospek outflow atau upflow (Hakim et al., 2017 dan Nugraha et al., 2018).

Selain pembuatan Peta FFD, dari data DEMNAS ini juga dilakukan interpretasi untuk mendapatkan circular feature. Circular feature ini diasumsikan sebagai sisa-sisa kegiatan vulkanisme di suatu daerah yang bisa menghasilkan anomali temperatur. Daerah yang memiliki circular feature dan sekitarnya bisa diasumsikan sebagai sumber panas (heat source) dari suatu sistem panas bumi (Hakim et al., 2017; Nugraha et al., 2018).

Data citra satelit yang diolah akan menghasilkan kelurusan untuk kemudian dibandingkan dengan struktur regional, sehingga dapat membedakan struktur yang diinterpretasikan sebagai sesar atau rekahan dengan struktur-struktur lain seperti antiklin dan sinklin.

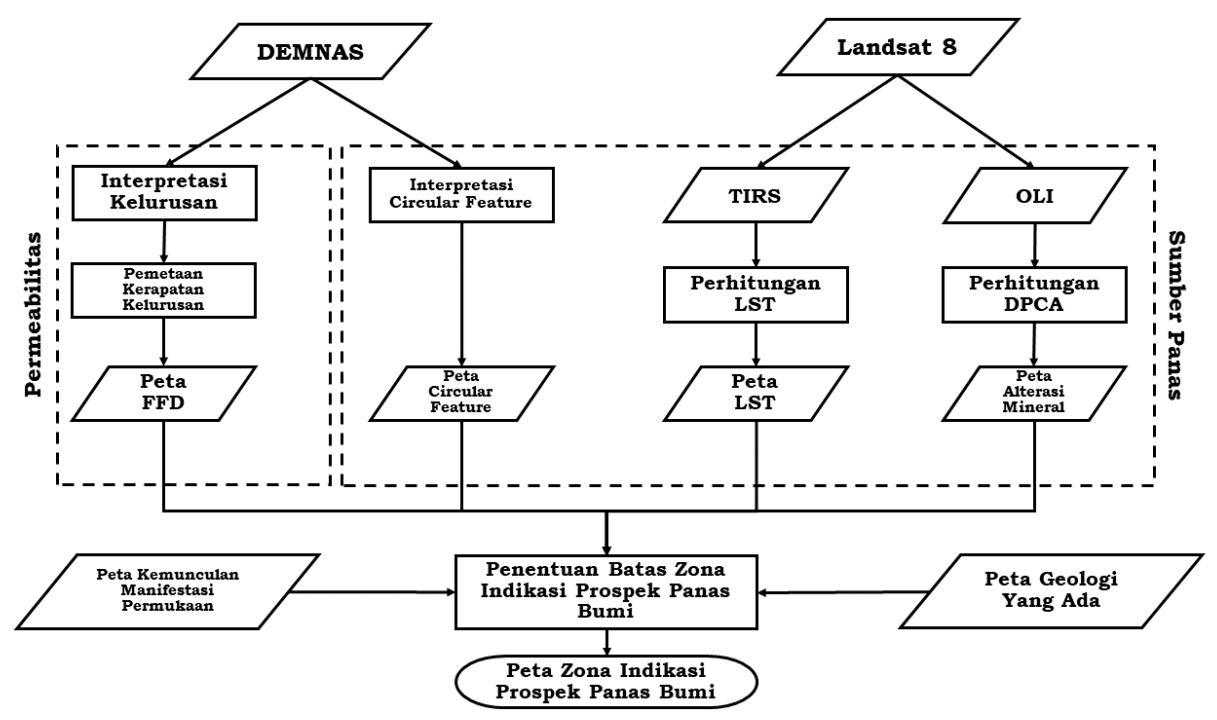

Gambar 2. Metodologi yang digunakan pada penelitian di Kabupaten Aceh Tengah 
Metoda Land SurfaceTemperature (LST) Metoda selanjutnya yang digunakan dalam penelitian ini yaitu analisis anomali dari Peta LST. Peta ini dihasilkan dari salah satu Band Thermal Infrared Sensor (TIRS) Landsat 8 yaitu band 10 dengan koreksikoreksi yang melibatkan Band Operational Land Imager (OLI) Landsat 8, dalam hal ini band yang digunakan dalam range spectral red dan near infrared yaitu band 4 dan band 5 (Avdan dan Jovanovska, 2016).

Untuk mendapatkan Peta LST, sebagaimana dijelaskan oleh Avdan dan Jovanovska (2016), setidaknya ada lima tahap yang harus dilalui. Kelima tahap tersebut terdiri dari perhitungan Top of Atmospheric Spectral Radiance, konversi pada Radiance to At-Sensor Temperature, perhitungan Normalized Difference Vegetation Index (NDVI), Proporsi Vegetasi, Land Surface Emissivity (LSE) dan LST.

\section{Perhitungan Top of Atmospheric Spectral Radiance}

Tahap pertama dari alur perhitungan untuk mendapatkan suhu permukaan yaitu memasukkan band 10 ke dalam aplikasi "R", selanjutnya dilakukan perhitungan Top of Atmospeheric (TOA) Spectral Radiance $(L \lambda)$ menggunakan formula yang diambil dari situs USGS, yaitu:

$L \lambda=M_{L} x Q_{c a l}-A_{L} O_{i}$

Dengan $M_{L}$ merupakan faktor skala perkalian radian, $Q_{c a l}$ adalah nilai piksel dalam digital number, $A_{L}$ merupakan faktor skala penambah radian untuk band dan $O_{i}$ adalah untuk band 10 .

\section{Konversi Radiance to At-Sensor Temperature}

Setelah Digital Number (DN) di konversi menjadi nilai referensi, nilai dari band TIRS dikonversi dari nilai spectral radiance menjadi nilai brightness temperature (BT) menggunakan nilai konstanta termal yang ada dalam metadata citra Landsat 8 (Tabel 1). Berikut merupakan nilai konstanta dalam metadata untuk citra Landsat 8 yang digunakan pada penelitian ini.

Tabel 1. Nilai Konstanta Pada Metadata Landsat 8 (USGS, 2020)

\begin{tabular}{cc}
\hline \multicolumn{3}{c}{ Konstanta Termal Band 10 } \\
\hline $\mathrm{K}_{1}$ & $1.321,08$ \\
$\mathrm{~K}_{2}$ & 77,89 \\
\hline Faktor Rescalling Band 10 \\
\hline $\mathrm{M}_{\mathrm{L}}$ & 0,000342 \\
$\mathrm{~A}_{\mathrm{L}}$ & 0,1 \\
\hline \multicolumn{3}{c}{ Koreksi Band 10 } \\
\hline $\mathrm{O}_{\mathrm{i}}$ & 0,29 \\
\hline
\end{tabular}

Untuk menghitung nilai brightness temperature (BT), dipergunakan persamaan sebagai berikut:

$B T=\frac{K_{2}}{\ln \left[\left(\frac{K_{1}}{L \lambda}\right)+1\right]}-273.15$

$K_{1}$ dan $K_{2}$ merupakan konstanta konversi termal yang nilainya dapat dilihat pada metadata dari citra, sebagaimana tercantum dalam tabel 1 (Avdan dan Jovanovska, 2016).

\section{Perhitungan NDVI}

Citra Landsat dari band visible dan nearinfrared digunakan untuk menghitung indeks vegetasi menggunakan transformasi atau biasa disebut Normal Difference Vegetation Index (NDVI). Perhitungan NDVI cukup penting karena keberadaan vegetasi merupakan faktor penting dalam penentuan suhu dan nilai NDVI ini merupakan gambaran keberadaan vegetasi tersebut (Avdan dan Jovanovska, 2016).

Dari nilai NDVI ini, selanjutnya akan dihitung nilai Proporsi Vegetasi $\left(P_{v}\right)$ dan dengan menggunakan nilai proporsi vegetasi tersebut akan di hitung Emisitivitas $(\varepsilon)$ (Avdan dan Jovanovska, 2016). Sedangkan untuk perhitungan NDVI menggunakan formula berikut ini:

$N D V I=\frac{N I R(\text { Band } 5)-R(\text { Band } 4)}{N I R(\text { Band } 5)+R(\text { Band } 4)}$.

Dimana, NIR merupakan nilai band 5 yaitu band near-infrared dan $\mathrm{R}$ adalah nilai band 


\section{MAKALAH ILMIAH}

4 yang merupakan band untuk warna merah. Perhitungan nilai Proporsi Vegetasi $\left(P_{v}\right)$ menggunakan formula dibawah ini:

$P_{v}=\left(\frac{N D V I-N D V I_{s}}{N D V I_{v}-N D V I_{s}}\right)^{2}$

Dengan $N D V I_{v}$ merupakan nilai NDVI untuk vegetasi dan $N D V I_{S}$ adalah nilai NDVI untuk tanah. Avdan (2015) menyarankan untuk menggunakan nilai global $N D V I_{v}$ sebesar 0,5 dan $N D V I_{S}$ sebesar 0,2.

\section{Perhitungan Land Surface Emissivity}

Land Surface Emissivity atau LSE $(\varepsilon)$ harus diketahui untuk menghitung LST, karena LSE merupakan faktor proporsional dari nilai radiance "blackbody" untuk memperkirakan nilai radiance yang dipancarkan dan efisiensi nilai energi panas yang ditransmisikan ke bidang atmosfer (Avdan dan Jovanovska, 2016). Nilai Land Surface Emissivity dihitung dengan menggunakan rumus:

$\varepsilon_{\lambda}=\varepsilon_{v \lambda} P_{v}+\varepsilon_{s \lambda}\left(1-P_{v}\right)+C_{\lambda}$

Dengan $\varepsilon_{v}$ dan $\varepsilon_{s}$ merupakan nilai emissivitas vegetasi dan tanah dan $C$ mewakili kekasaran bidang dengan nilai konstanta 0,005 (nilai $C=0$ untuk bidang datar dan homogen).

\section{Perhitungan LST}

Tahap terakhir seperti dijelaskan Avdan dan Jovanovska (2016) adalah perhitungan LST atau $T_{S}$ dengan menggunakan formula:

$$
T_{S}=\frac{B T}{\left\{1+\left[\left(\frac{\lambda B T}{\rho}\right) \ln \varepsilon_{\lambda}\right]\right\}}
$$

Dimana $T_{S}$ adalah LST dalam derajat celcius $\left({ }^{\circ} \mathrm{C}\right)$, BT adalah nilai BT pada sensor, $\lambda$ ialah panjang gelombang radiance (nilai $\lambda=0,005$ akan digunakan), merupakan hasil perhitungan emisivitas dan nilai $\rho$ yaitu :

$\rho=h \frac{c}{\sigma}=1.438 \times 10^{-2} \mathrm{mK}$

\section{Metoda DPCA}

Citra Landsat 8 memiliki 11 band dengan dua kelompok band yaitu Operational Land Imager (OLI) dan Thermal Infrared Sensor (TIRS). Band OLI pada Landsat 8 menangkap 9 band dari visible nearinfrared (VNIR) dan short wave infrared SWIR (NASA, 2013).

Untuk mengidentifikasi material mineral di permukaan bumi khususnya di daerah penelitian digunakan band 2 sampai dengan band 7 (Salamba et al., 2019). Pilihan band pada Landsat 8 yang bisa digunakan untuk mengidentifikasi mineral dapat dilihat pada Gambar 3 dibawah ini.

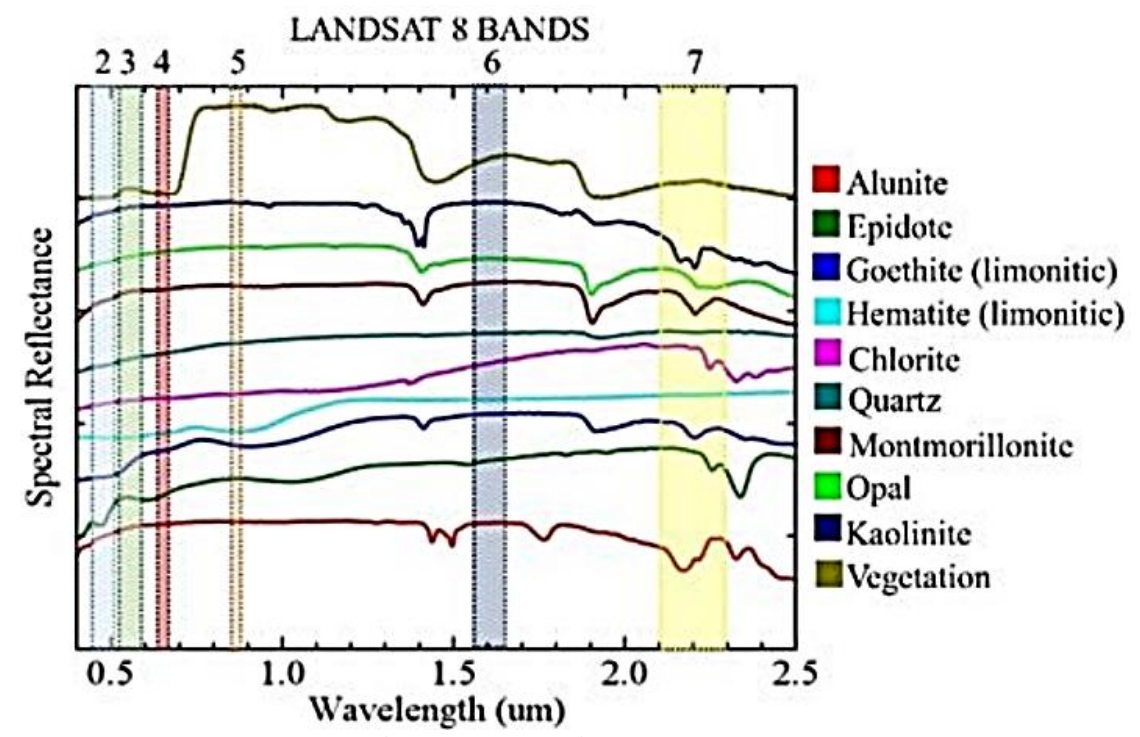

Gambar 3. Hubungan Antara Spectral Reflectance Landsat 8 dan Beberapa Mineral (Salamba et al., 2019) 
Citra hasil rasio band Landsat 8 ini dipergunakan sebagai input algoritma DPCA sesuai yang telah dilakukan Salamba et al. (2019). Ada 2 (dua) jenis input yaitu rasio band vegetasi dan mineral. Berdasarkan hasil penelitian di atas, rasio band vegetasi merupakan rasio band yang paling optimum untuk mendapatkan indikasi vegetasi paling kontras. Sedangkan rasio band mineral akan menunjukan rasio optimum yang diharapkan menunjukan kenampakan mineral ubahan dalam citra Landsat 8. Tabel 2 menunjukan rasio band vegetasi dan mineral selengkapnya.

Tabel 2. Rasio Band Pada Citra Landsat 8 sebagai Input DPCA (Salamba et al., 2019)

\begin{tabular}{ccc}
\hline Mineral & $\begin{array}{c}\text { Rasiore Band } \\
\text { Vegetasi }\end{array}$ & $\begin{array}{c}\text { Rasio Band } \\
\text { Mineral }\end{array}$ \\
\hline Quartz & Band 3/band 4 & Band 7/band 2 \\
Alunite & Band 5/band 2 & Band 6/band 7 \\
Kaolinite & Band 5/band 4 & Band 6/band 7 \\
Chlorite & Band 5/band 3 & Band 6/band 2 \\
Epidote & Band 3/band 4 & Band 6/band 2
\end{tabular}

\section{DATA YANG DIGUNAKAN}

\section{CITRA DEMNAS}

Citra DEM pada daerah penelitian merupakan hasil mosaik dari enam Citra DEMNAS. Citra tersebut terdiri dari DEMNAS 0520-51, DEMNAS 0520-53, DEMNAS 0520-61, DEMNAS 0520-23, DEMNAS 0520-24, dan DEMNAS 0520-33.

Citra DEMNAS ini dapat diunduh melalui situs web Seamless Digital Elevation Model dan Batimetri Nasional yang dikelola oleh Badan Informasi Geospasial. DEMNAS ini dibangun dari beberapa sumber data yang meliputi data IFSAR (resolusi $5 \mathrm{~m}$ ), TERRASAR-X (resolusi 5 meter) dan ALOS PALSAR (resolusi 11,25 meter), dengan menambahkan data masspoint hasil stereo-plotting. Resolusi spasial DEMNAS adalah 0,27-arc second (8 meter), dengan menggunakan datum vertikal EGM2008 (Badan Informasi Geospasial, 2020).

\section{CITRA LANDSAT}

Citra Landsat yang dipergunakan dalam penelitian ini berupa citra yang diunduh dari situs USGS (https://earthexplorer.usgs. gov/). Berdasarkan metadata citra tersebut, citra ini diakuisisi pada tanggal 6 Januari 2019 pada path 130 dan row 57 dengan azimuth dan ketinggian matahari adalah $135,97^{\circ}$ dan $51,86^{\circ}$. Citra ini memiliki persentase area yang tertutup awan sebesar 6,04\% (USGS, 2020).

Pada Landsat 8 terdapat sembilan band yang termasuk band OLI dan dua band termasuk TIRS. Band OLI tersebut adalah band 1, 2, 3, 4, 5, 6, 7, 8, dan 9 . Resolusi spasial band OLI yaitu 30 meter kecuali band 8 yang merupakan band pankromatik dengan resolusi spasial 15 meter. Sedangkan band TIRS adalah band 10 dan 11 dengan resolusi masing-masing 100 meter. Karakteristik selengkapnya dapat dilihat di Tabel 3.

Tabel 3. Karakteristik Band Pada Landsat 8 (NASA, 2013)

\begin{tabular}{ccc}
\hline Band & Panjang Gelombang & Resolusi \\
\hline 1 & $0,433-0,453 \mu \mathrm{m}$ & $30 \mathrm{~m}$ \\
2 & $0,450-0,515 \mu \mathrm{m}$ & $30 \mathrm{~m}$ \\
3 & $0,525-0,600 \mu \mathrm{m}$ & $30 \mathrm{~m}$ \\
4 & $0,630-0,680 \mu \mathrm{m}$ & $30 \mathrm{~m}$ \\
5 & $0,845-0,885 \mu \mathrm{m}$ & $30 \mathrm{~m}$ \\
6 & $1,580-1,660 \mu \mathrm{m}$ & $30 \mathrm{~m}$ \\
7 & $2,100-2,300 \mu \mathrm{m}$ & $30 \mathrm{~m}$ \\
8 & $0,500-0,680 \mu \mathrm{m}$ & $15 \mathrm{~m}$ \\
9 & $1,360-1,390 \mu \mathrm{m}$ & $30 \mathrm{~m}$ \\
10 & $10,30-11,30 \mu \mathrm{m}$ & $100 \mathrm{~m}$ \\
11 & $11,50-12,50 \mu \mathrm{m}$ & $100 \mathrm{~m}$ \\
\hline
\end{tabular}

Untuk penelitian ini digunakan dua perangkat lunak untuk menghitung, menganalisis dan menampilkan hasil analisis penginderaan jauh, yaitu ArcGIS 10 dan R. ArcGIS sendiri merupakan perangkat lunak Sistem Informasi Geografi (SIG) untuk menganalisis citra dan menampilkan hasil akhir. R ( $\mathrm{R}$ Core Team, 2013) sebenarnya merupakan perangkat lunak statistik yang dipergunakan untuk 
melakukan perhitungan beberapa metoda dalam penelitian ini.

Perangkat lunak Sistem Informasi Geografis (SIG) ArcGIS 10 digunakan untuk mengaplikasikan metoda FFD dan membuat peta hasil akhir. ArcGIS 10 ini dapat mengkonversi citra DEM dari DEMNAS menjadi hillshade DEM dengan berbagai azimuth menggunakan function Hillshade yang merupakan bagian dari Tools 3D Analyst atau Spatial Analyst. Hasil dari interpretasi kelurusan citra hillshade tersebut, selanjutnya dibuat peta kerapatan kelurusan menggunakan function Kernel Density untuk garis yang merupakan bagian dari Tools Spatial Analyst.

Penelitian ini juga menggunakan perangkat lunak " $R$ " untuk perhitungan LST dan DPCA. Meskipun penerapan kedua metoda tersebut bisa menggunakan ArcGIS, namun dipilih $R$ karena kemudahan dan ketersediaan serta keberulangannya tanpa penulisan algoritma yang rumit dalam proses pengolahan datanya. Terdapat tiga Paket $\mathrm{R}$ utama yang digunakan dalam penelitian ini yaitu raster, $s p$ dan FactoMineR.

Paket raster (Hijmans, 2020) dan sp (Bivand et al,. 2013) digunakan untuk melakukan pengolahan dan analisis citra, sedangkan FactoMineR (Lê, Josse, dan Husson, 2008) untuk pengolahan dan analisis metoda PCA.

\section{GEOLOGI}

Aktivitas tektonik pada zona subduksi yang terdapat di Pulau Sumatra merupakan akibat adanya tumbukan antara Lempeng Eurasia dan Lempeng Indo Australia (Hall, 2002). Lebih lanjut, Hall (2002) menyebutkan bahwa zona subduksi di Pulau Sumatra sudah terjadi sejak Jaman Kapur Akhir hingga kini dan telah menghasilkan adanya jalur sesar serta jalur magmatik yang membentuk rangkaian gunung api di sepanjang bagian barat Pulau Sumatra, salah satunya di Kabupaten Aceh Tengah, yaitu di sekitar Gunung Geureudong, Gunung Salah Nama dan Gunung Telege.

Cameron et al. (1983) menjelaskan bahwa di Kabupaten Aceh Tengah terdapat litologi yang berumur Pra Tersier hingga Kuarter (Gambar 4). Batuan Pra Tersier di Kabupaten Aceh Tengah berupa batuan metasedimen dan metamorf yang keterdapatannya sebagian tersingkap di sepanjang Pegunungan Bukit Barisan. Sedangkan, keberadaan batuan Kuarter di dominasi oleh batuan vulkanik yang berupa batu apung, lava dan aliran piroklastik yang berasal dari Gunung Geureudong, Gunung Salah Nama dan Gunung Telege. Sementara itu, kehadiran batuan terobosan dijumpai di beberapa tempat pada bagian barat daerah penelitian yang terdiri dari gabro, granodiorit dan batuan metamorf.

Struktur geologi yang terdapat di daerah penelitian berupa kelurusan, sesar normal dan sesar naik yang berarah barat lauttenggara, utara-selatan dan timur lauttenggara, serta adanya beberapa struktur depresi di sekitar tubuh gunung api. Kehadiran struktur geologi tersebut diduga mengontrol kemunculan manifestasi di daerah penelitian.

Cameron et al. (1983) menyebutkan bahwa manifestasi panas bumi yang terdapat di daerah penelitian berupa mataair panas, sedangkan Anonim (2014) menjelaskan bahwa pada bagian utara daerah penelitian terdapat manifestasi mata air panas Wih Porak yang memiliki tipe air bikarbonat.

Secara ringkas, kondisi geologi dan lokasi manifestasi daerah penelitian terangkum pada Gambar 4. 

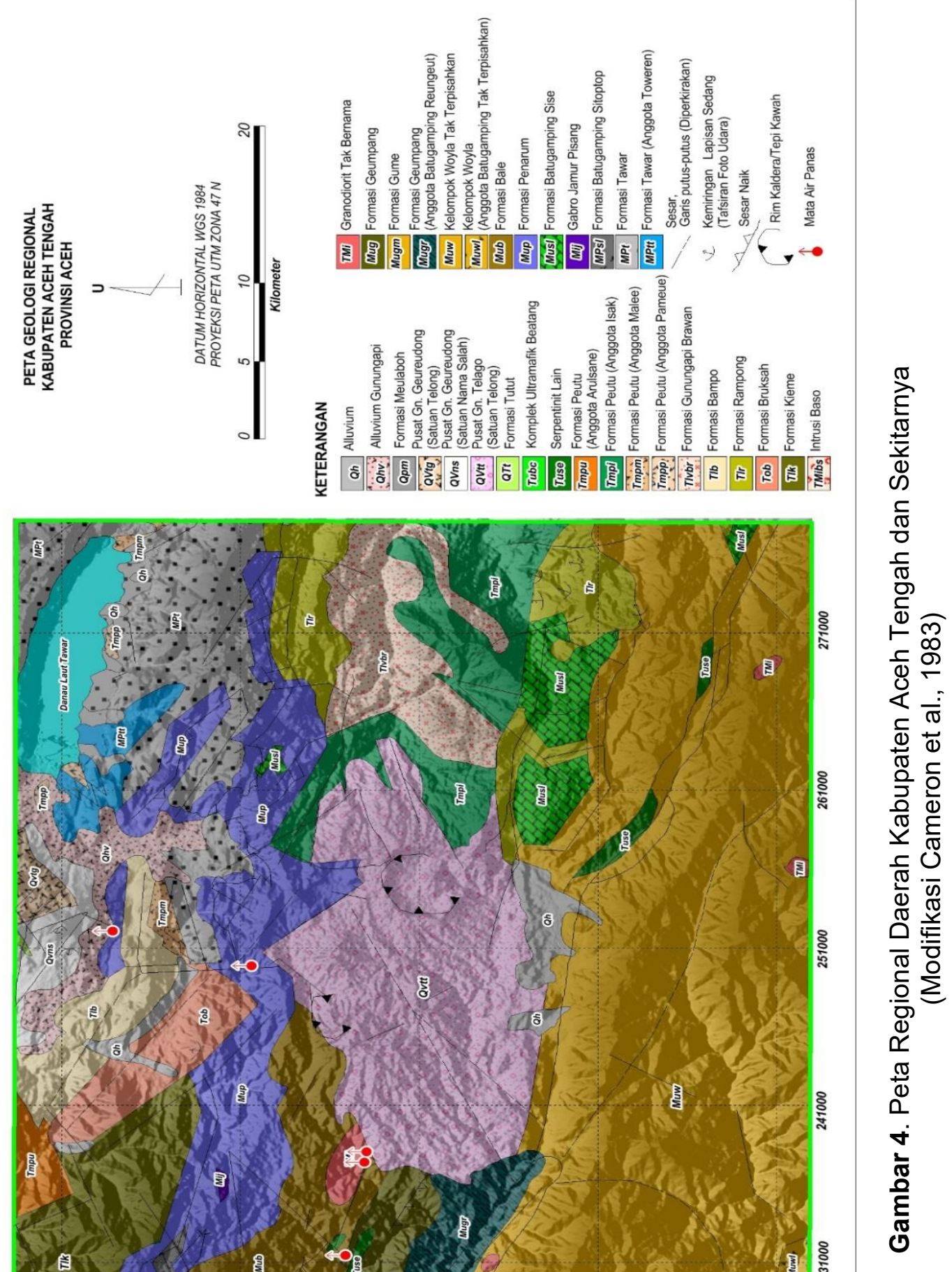


\section{MAKALAH ILMIAH}

\section{HASIL DAN ANALISIS}

\section{Hasil Interpretasi Kelurusan}

Gambar 5 merupakan hasil transformasi citra DEMNAS menggunakan fungsi hillshade. Hillshade merupakan representasi 3D permukaan bumi dalam bentuk greyscale dengan posisi relatif cahaya (matahari) sebagai dasar pembentukan bayangan dari citra. Transformasi ini menggunakan derajat
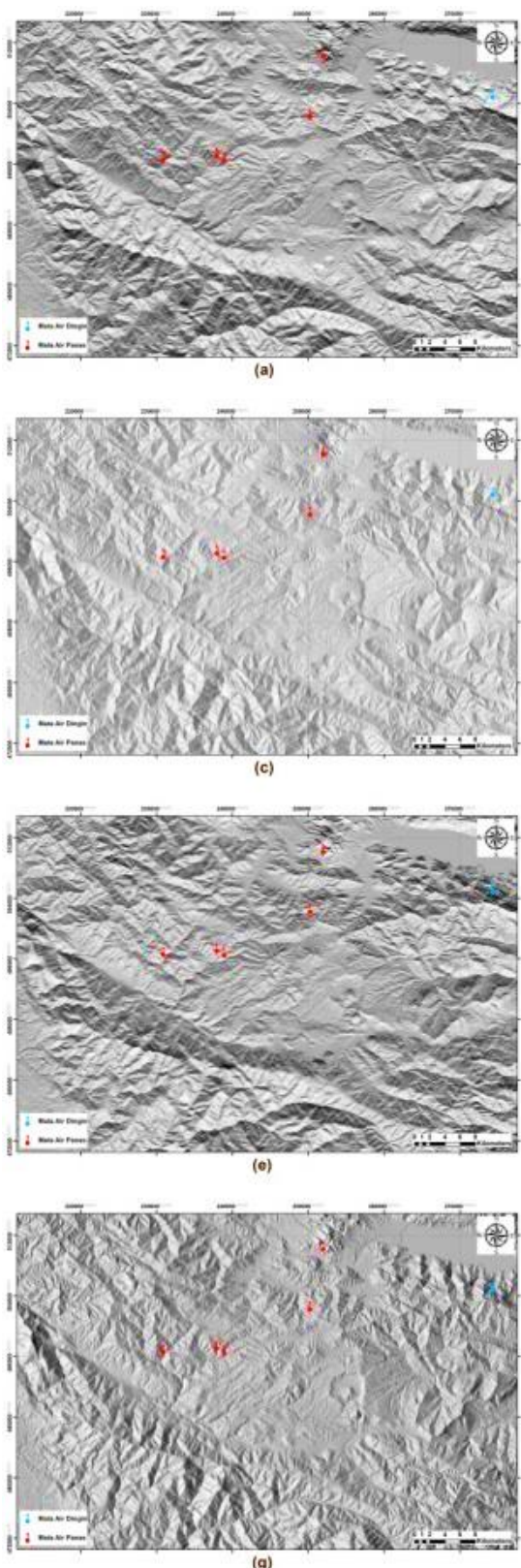

posisi ketinggian dari bidang datar dan derajat azimuth cahaya.

Untuk fitur struktur geologi, azimuth dan posisi ketinggian $45^{\circ}$ merupakan posisi yang biasanya digunakan untuk interpretasi. Namun, untuk mendeteksi semua fitur struktur geologi, 9 (Sembilan) jenis derajat azimuth digunakan untuk derajat posisi ketinggian yang sama yaitu $45^{\circ}$. Gambar 5 menunjukan hasil masingmasing transformasi azimuth.
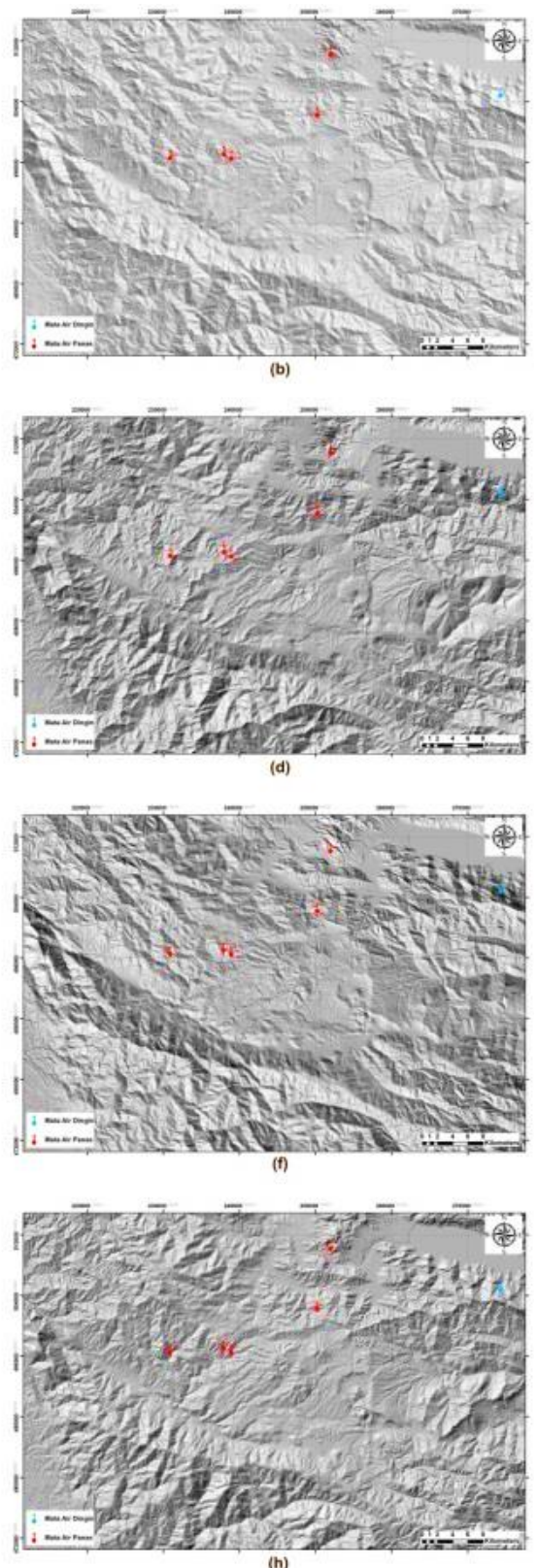

Gambar 5. Transformasi Hillshade DEMNAS Lokasi Studi Dengan Ketinggian $45^{\circ}$ (a)

Azimuth $0^{\circ}$; (b) Azimuth $45^{\circ}$; (c) Azimuth $90^{\circ}$; (d) Azimuth $135^{\circ}$; (e) Azimuth $180^{\circ}$;

(f) Azimuth $225^{\circ}$; (g) Azimuth $270^{\circ}$; dan (h) Azimuth 315 


\section{MAKALAH ILMIAH}

Gambar 6 (a) memperlihatkan gambaran struktur geologi pada daerah penelitian yang merupakan gabungan antara interpretasi visual dari transformasi hillshade dan peta regional yang ada. Sedangkan, gambar 6 (b) merupakan peta densitas kelurusan atau Fault and Fracture
Density Map dari struktur geologi gabungan sebagaimana tergambar pada Gambar 6 (a). Gambar 6 (b) menunjukkan bahwa mata air panas tidak berada pada area dengan densitas kelurusan tinggi, namun berada di bagian tepi dari daerah dengan densitas kelurusan yang tinggi.
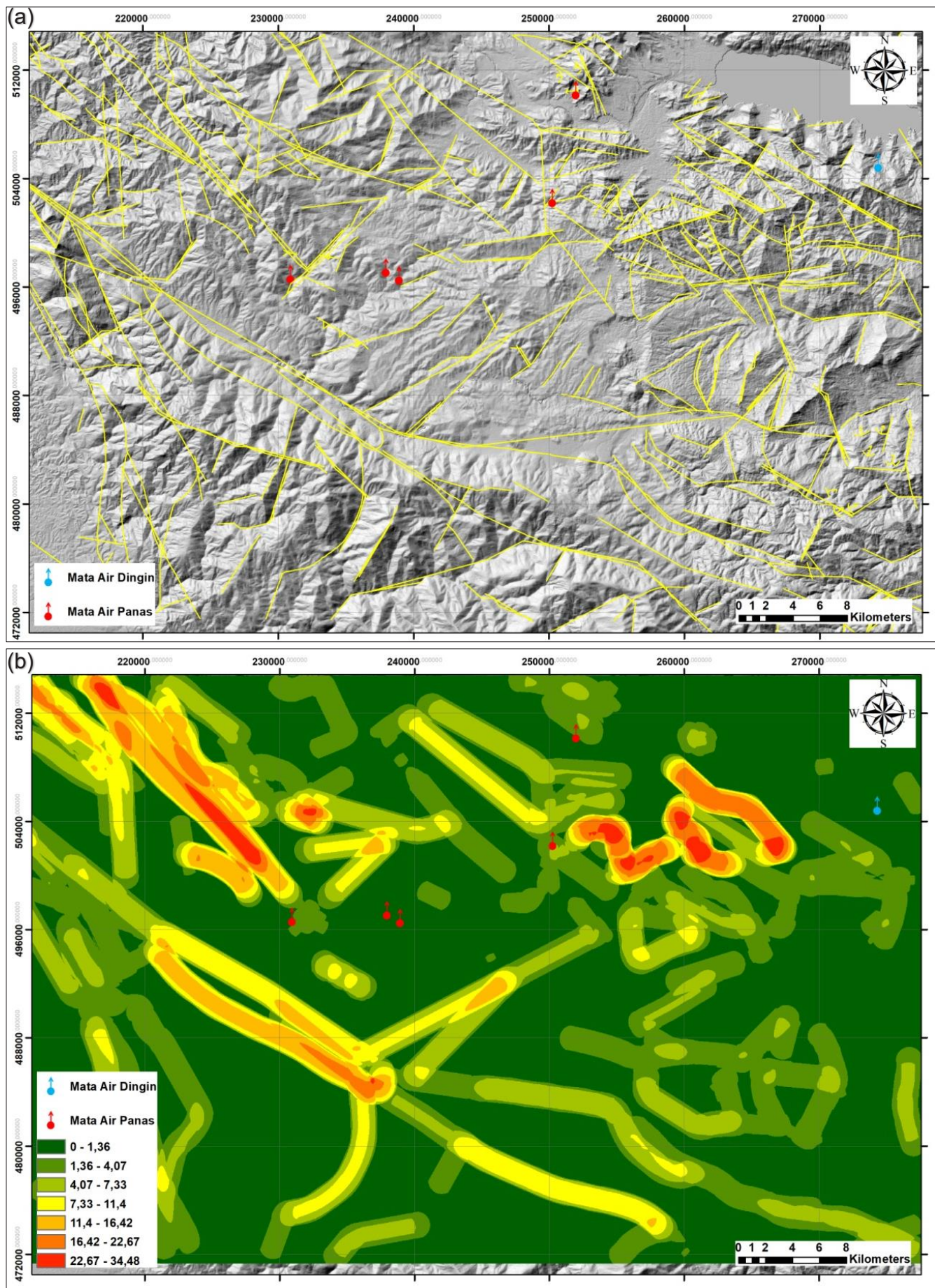

Gambar 6. (a) Struktur Geologi Hasil Gabungan Interpretasi Transformasi Hillshade DEMNAS dan Peta Struktur Geologi Regional, (b) Peta Densitas Kelurusan atau Fault and Fracture Density Map 


\section{MAKALAH ILMIAH}

\section{Hasil Interpretasi Circular Feature}

Gambar 7 merupakan peta interpretasi circular feature yang merupakan gabungan hasil interpretasi dari DEMNAS dan peta geologi regional. Terdapat enam circular feature selain circular feature yang sudah teridentifikasi pada peta geologi regional lembar Takengon. Fitur ini merupakan salah satu fitur yang dicari dalam eksplorasi panas bumi, karena dapat menjadi salah satu indikator adanya sumber panas pada sistem panas bumi.

\section{Hasil Analisis Citra Landsat 8}

Penelitian ini menggunakan empat kombinasi band RGB citra Landsat 8 yaitu natural color, false color (urban), color infrared (vegetation) dan natural atmospheric removal. Interpretasi dilakukan dengan mengkombinasikannya dengan peta topografi. Tabel 4 menunjukan beberapa kombinasi band citra Landsat 8 yang dapat digunakan untuk berbagai tujuan termasuk kombinasi band yang digunakan dalam penelitian ini.
Tabel 4. Kombinasi Band RGB Landsat 8 Untuk Berbagai Tujuan Penggunaan (USGS, 2020)

\begin{tabular}{cc}
\hline Tujuan Penggunaan & Kombinasi \\
\hline Natural Color & 432 \\
False Color (urban) & 764 \\
Color Infrared (vegetation) & 543 \\
Agriculture & 652 \\
Atmospheric Penetration & 765 \\
Healthy Vegetation & 562 \\
Land/Water & 564 \\
Natural With Atmospheric & 753 \\
Shortwave Infrared & 754 \\
Vegetation Analysis & 654 \\
\hline
\end{tabular}

Gambar 8 (a) dan (b) merupakan citra natural color dengan pengayaan menggunakan histogram equalizer. Dari gambar tersebut dapat diinterpretasikan bahwa bagian barat, barat daya dan selatan dari daerah penelitian serta sebelah selatan Danau Laut Tawar merupakan wilayah yang ditutupi oleh vegetasi, diindikasikan dengan warna hijau tua yang dominan.

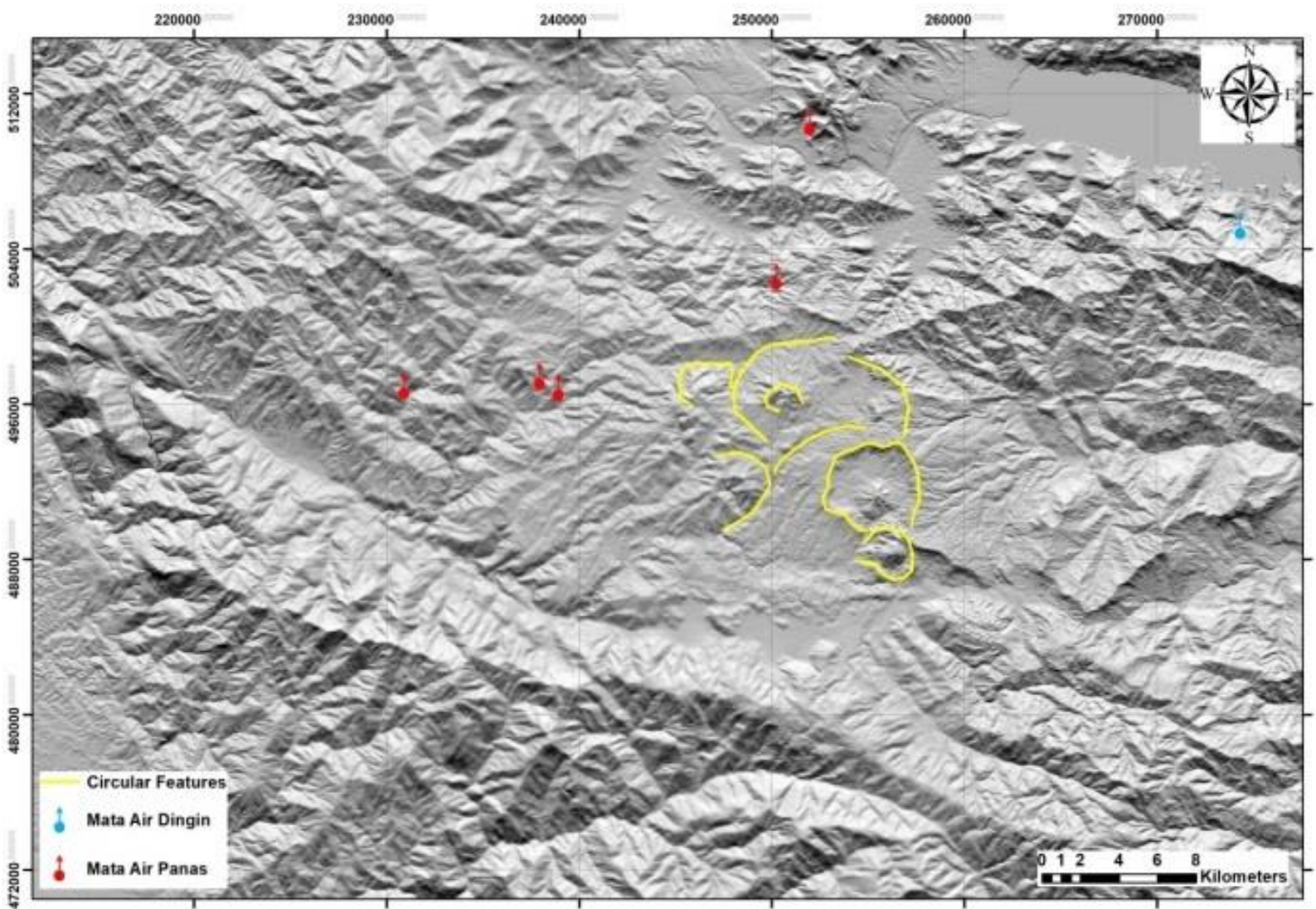

Gambar 7. Hasil Interpretasi Circular Feature Pada Daerah Penelitian 
Gambar 8 (c) menunjukkan bahwa daerah tengah dan utara (sebelah barat Danau Laut Tawar) merupakan wilayah perkotaan atau wilayah bukaan yang tidak tertutup vegetasi. Sedangkan, bagian tengah dan utara dari daerah penelitian secara berurutan merupakan Wilayah Kecamatan Atu Lintang dan Kota Takengon. Hal ini diindikasikan dengan warna putih dan biru.

Gambar 8 (d) menegaskan bahwa vegetasi yang menutupi daerah bagian barat, barat daya dan selatan daerah penelitian lebih lebat/rapat dibandingkan dengan vegetasi yang menutupi daerah sebelah selatan Danau Laut Tawar yang diperlihatkan dengan warna hijau tua.

Sementara itu, apabila interpretasi gambar 8 (c) digabungkan dengan gambar 8 (d), Kota Takengon yang berada disebelah
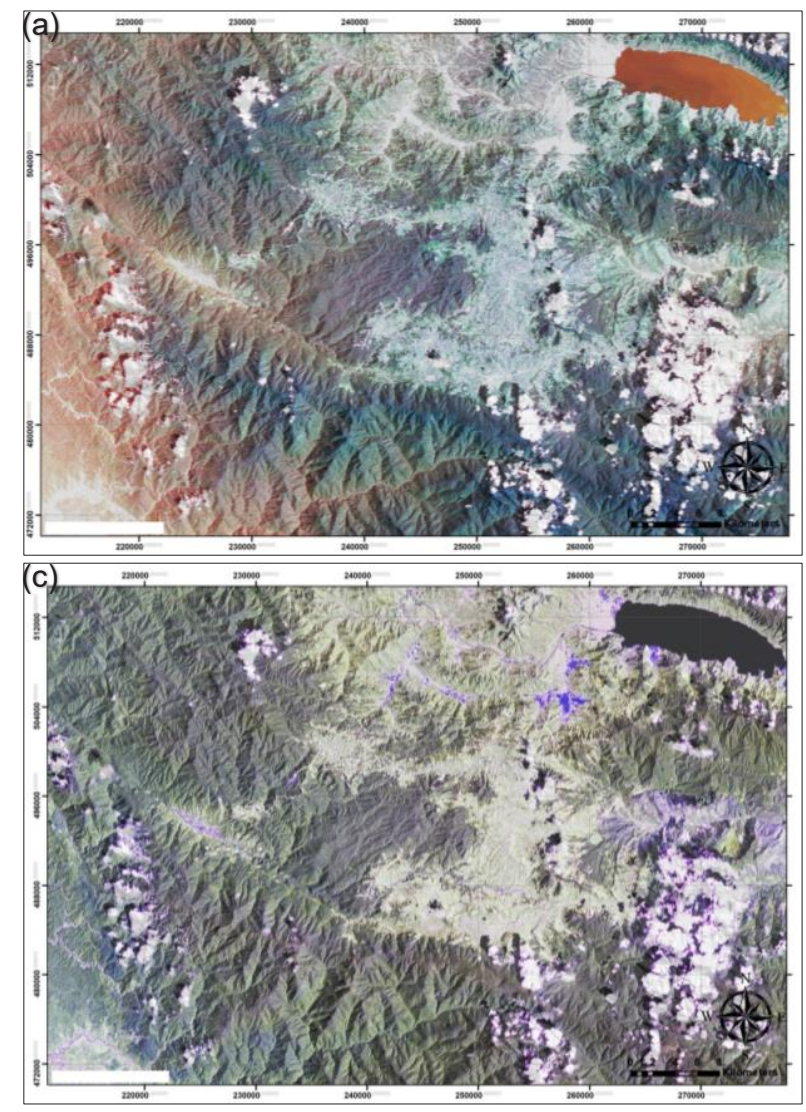

Gambar 8. Citra Hasil Kombinasi Band dari Citra Landsat 8,

(a) Natural Colour; (b) Natural Atmospheric Removal; (c) False Colour (Urban);

(b) dan (d) Colour Infrared (Vegetation)

barat Danau Laut Tawar memiliki bangunan-bangunan yang lebih rapat dibandingkan daerah di Kecamatan Atu Lintang. Hal ini diindikasikan dengan warna biru muda.

\section{Hasil Perhitungan LST}

Gambar 9 menunjukan hasil perhitungan LST daerah penelitian berdasarkan Landsat 8. Hasil LST pada daerah ini memiliki kisaran cukup lebar yaitu $31,7^{\circ} \mathrm{C}$ dengan nilai maksimum $37,6^{\circ} \mathrm{C}$ dan minimum $5,9^{\circ} \mathrm{C}$. Kisaran yang lebar ini dikarenakan adanya bagian yang tertutup awan yang memiliki perbedaan suhu cukup jauh dengan bagian yang tidak tertutupi awan. Nilai minimum pada citra ini berada pada bagian awan tersebut. Awan tersebut terlihat sangat jelas (Gambar 7). Namun, karena interpretasi berfokus pada anomali suhu tinggi, maka hal ini dapat diabaikan.
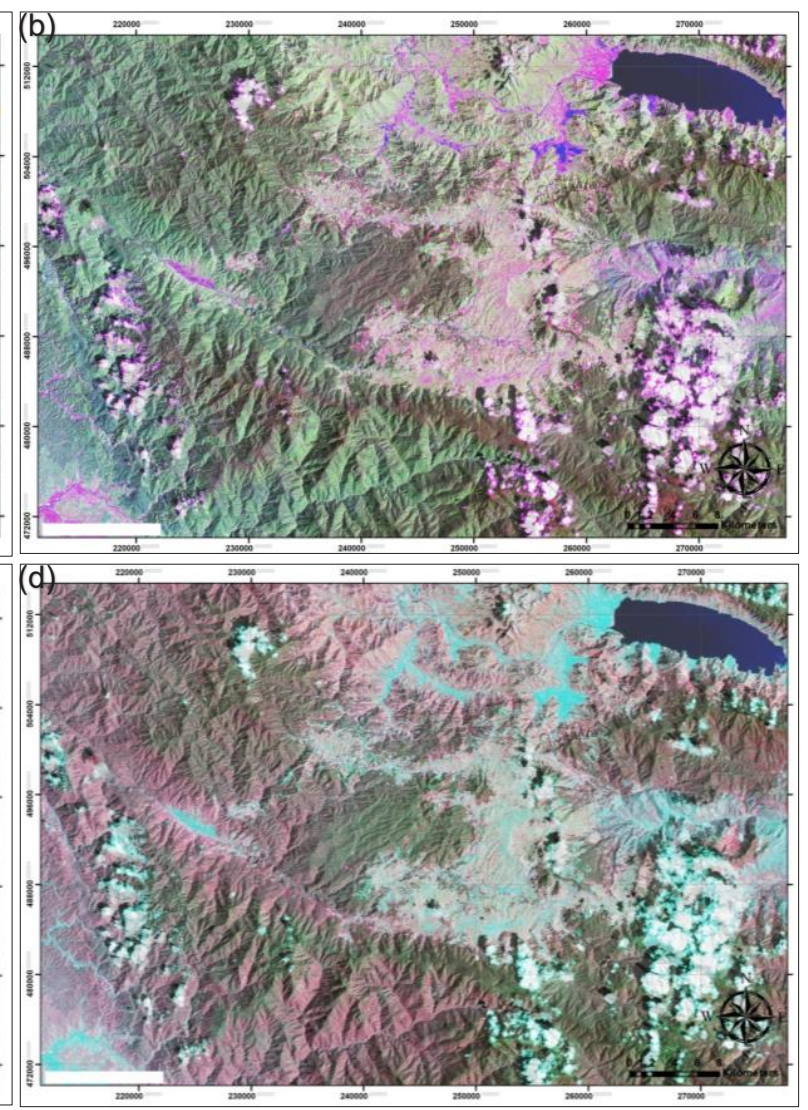


\section{MAKALAH ILMIAH}

Berdasarkan Gambar 9 terdapat tiga daerah yang memiliki anomali suhu tinggi. Daerah pertama dan kedua merupakan Takengon. Nilai maksimum pada citra ini berada pada daerah Kota Takengon dengan kisaran suhu antara $33^{\circ} \mathrm{C}$ sampai dengan $37,6^{\circ} \mathrm{C}$

Daerah anomali ketiga berada di bagian tengah daerah penelitian yaitu di sekitar daerah Kecamatan Atu Lintang. Daerah anomali suhu tinggi ini berada pada kawasan circular feature. Kisaran suhu permukaan pada daerah ini berkisar antara $29^{\circ} \mathrm{C}$ sampai dengan $33^{\circ} \mathrm{C}$.

\section{Hasil Perhitungan DPCA}

Berdasarkan perhitungan DPCA (Tabel 5) menunjukan bahwa nilai proporsi variasi didominasi PC1 hingga lebih dari $85 \%$, sehingga PC2 bisa dianggap hanya sebagai noise. Berdasarkan nilai persentase variasi tersebut, maka penggunaan PC1 diharapkan dapat menjelaskan sekitar $85 \%$ fenomenafenomena yang terjadi pada daerah penelitian yang berasal dari data kedua input algoritma DPCA tersebut. wilayah Kota Takengon termasuk di sebelah barat daya Kota

Secara umum, hasil analisis DPCA memperlihatkan bahwa indikasi keterdapatan mineral berada pada wilayah terbuka yang tidak tertutup vegetasi. Posisi keterdapatan masing-masing mineral tidak unik. Sehingga dalam satu piksel didapatkan beberapa mineral yang dominan. Kemungkinan hal ini dapat terjadi disebabkan oleh lebarnya kisaran jendela spectral pada band citra Landsat 8 sehingga belum dapat menampilkan spektrum yang unik untuk tiap mineral pada lokasi tertentu.

Tabel 5. Bobot Variasi PC1 dan PC2 Metoda DPCA untuk Masing-Masing Mineral

\begin{tabular}{ccc}
\hline Mineral & PC1 & PC2 \\
\hline Kuarsa & $85,00 \%$ & $15,00 \%$ \\
Alunit & $99,25 \%$ & $0,75 \%$ \\
Kaolinit & $99,36 \%$ & $0,64 \%$ \\
Klorit & $93,28 \%$ & $6,72 \%$ \\
Epidot & $95,65 \%$ & $4,35 \%$ \\
\hline
\end{tabular}

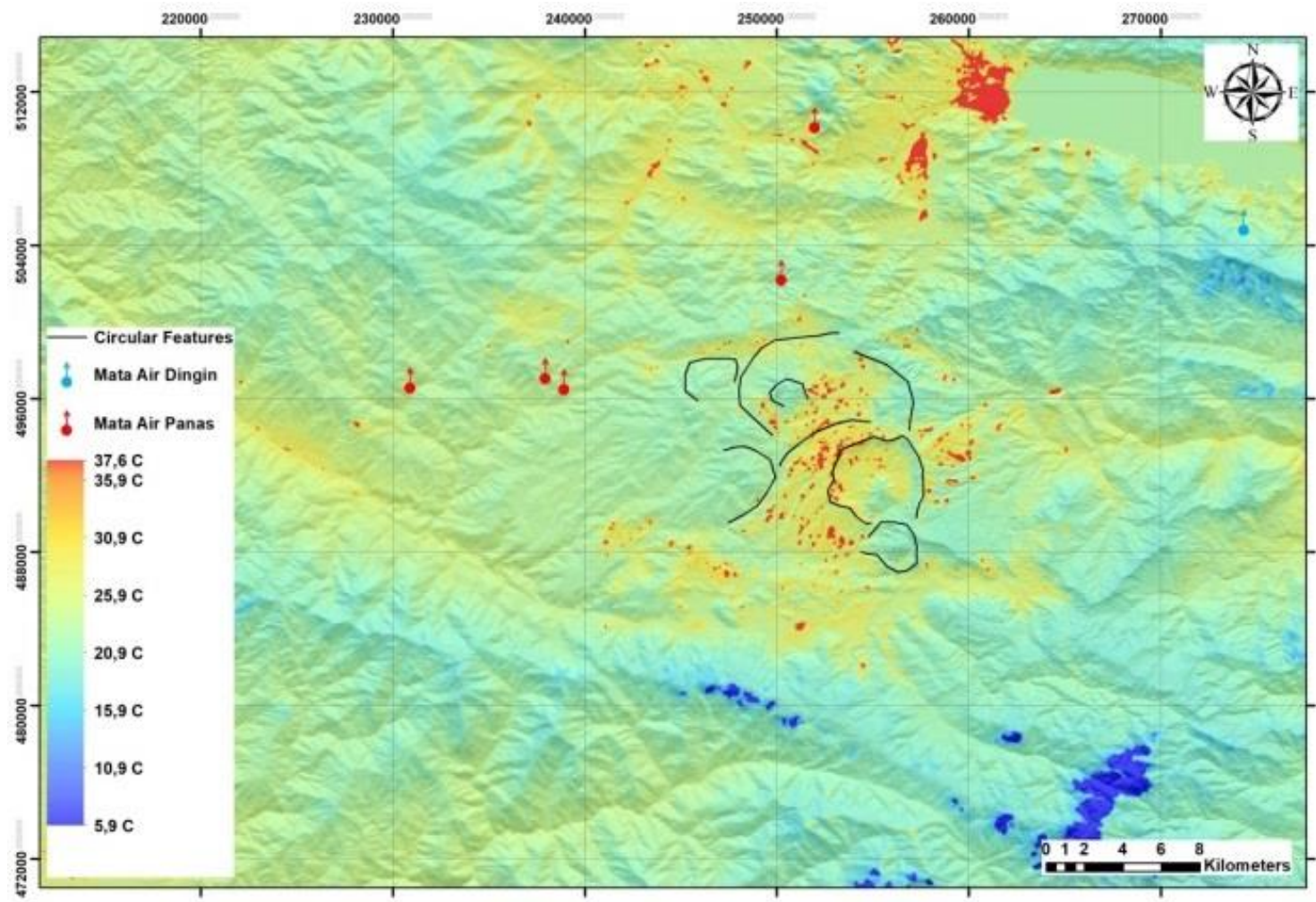

Gambar 9. Citra Suhu Permukaan - Land Surface Temperature (LST) dari Landsat 8 
Gambar 10 merupakan hasil akhir proses penerapan metoda DPCA. Sebagaimana dijelaskan pada bagian sebelumnya bahwa dua perbandingan band citra Landsat 8 yang mewakili citra dominan mineral dan dominan vegetasi menjadi input algoritma PCA. Hasil pengolahan dari algoritma PCA tersebut selanjutnya diklasifikasikan menjadi 7 (tujuh) kelas menggunakan metoda Natural Break di ArcMap 10.

Secara umum anomali mineral pada gambar-gambar tersebut sulit untuk diinterpretasikan. Terdapat anomali rendah pada nilai PC1 untuk mineral kuarsa, dan kaolinit, yang diindikasikan dengan warna merah pada Gambar 10 (a) dan 10 (c). Anomali mineral kuarsa tampak lebih jelas dibandingkan anomali kaolinit Sedangkan anomali tinggi, diindikasikan dengan warna hijau menunjukan danau dan awan. Namun kenampakan nilai anomali rendah untuk mineral kuarsa dan epidot tersebut berada pada posisi spasial piksel yang sama. Hal ini menyebabkan pada piksel tersebut tidak dapat diinterpretasikan sebagai anomali nilai baik untuk mineral kuarsamaupun epidot.

Untuk mineral alunit yang ditunjukan pada Gambar 10 (b) meskipun menunjukan anomali rendah (warna merah), akan tetapi sulit diinterpretasikan karena berada pada area dengan vegetasi tebal yang memiliki nilai anomali serupa dengan alunit.

Gambar 10 (d) dan (e) merupakan hasil akhir DPCA untuk mineral klorit dan epidot. Gambar 10 (d) menunjukan tidak nampak adanya nilai anomali rendah yang diharapkan sebagai indikasi keberadaan mineral klorit. Gambar 10 (d) hanya menunjukan anomali tinggi yang menunjukan posisi danau dan daerah yang tertutupi awan. Untuk Gambar 10 (e) menunjukan nilai anomali rendah yang cukup jelas (warna merah) untuk daerah tengah dan utara daerah penelitian.

Berdasarkan hal tersebut, sulit untuk dapat memisahkan antara zona argilik lanjut dan zona propilitik yang tumpang tindih. Zona argilik lanjut menggambarkan indikator zona bersuhu rendah yang direpresentasikan oleh mineral sekunder seperti kuarsa, alunit dan kaolinit. Sedangkan zona propilitik direpresentasikan oleh klorit dan epidot yang menggambarkan zona bersuhu tinggi.

\section{PEMBAHASAN}

Indikasi keberadaan sumber panas di daerah penelitian diperkirakan berada di sekitar circular feature, tepatnya pada komplek vulkanik Gunung Telege yang berada di daerah Kecamatan Atu Lintang. Circular feature tersebut diperkirakan merupakan sisa-sisa aktivitas vulkanik Gunung Telege berumur Kuarter (Cameron et al., 1983) yang masih memiliki sisa-sisa panas. Indikasi sumber panas (heat source) ini didukung oleh metoda LST yang memperlihatkan adanya anomali suhu permukaan.

Topografi daerah penelitian yang berada pada daerah tinggian (high terrain), memungkinkan adanya pola aliran fluida dari daerah dengan elevasi tinggi di sekitar Komplek Vulkanik Gunung Telege, menuju ke elevasi rendah baik ke bagian barat dan utara Gunung Telege maupun ke lembah serta aliran sungai hingga ke bagian selatan daerah penelitian. Dalam hal ini, fluida yang diduga berasal dari air meteorik akan mengalami penetrasi secara vertikal dan akhirnya memasuki sistem panas bumi hingga terjadi proses lepasan (discharge) sebagai fluida manifestasi panas bumi di permukaan. Diduga keberadaan zona outflow terletak pada elevasi rendah, yaitu di sekitar lembah dan aliran sungai yang terletak pada bagian barat dan utara komplek vulkanik Gunung Telege (Gambar 11). Namun demikian, untuk mengetahui secara akurat tentang pola aliran fluida, zona outflow dan zona upflow diperlukan penelitian lebih lanjut melalui penggunaan metoda geokimia. 


\section{MAKALAH ILMIAH}
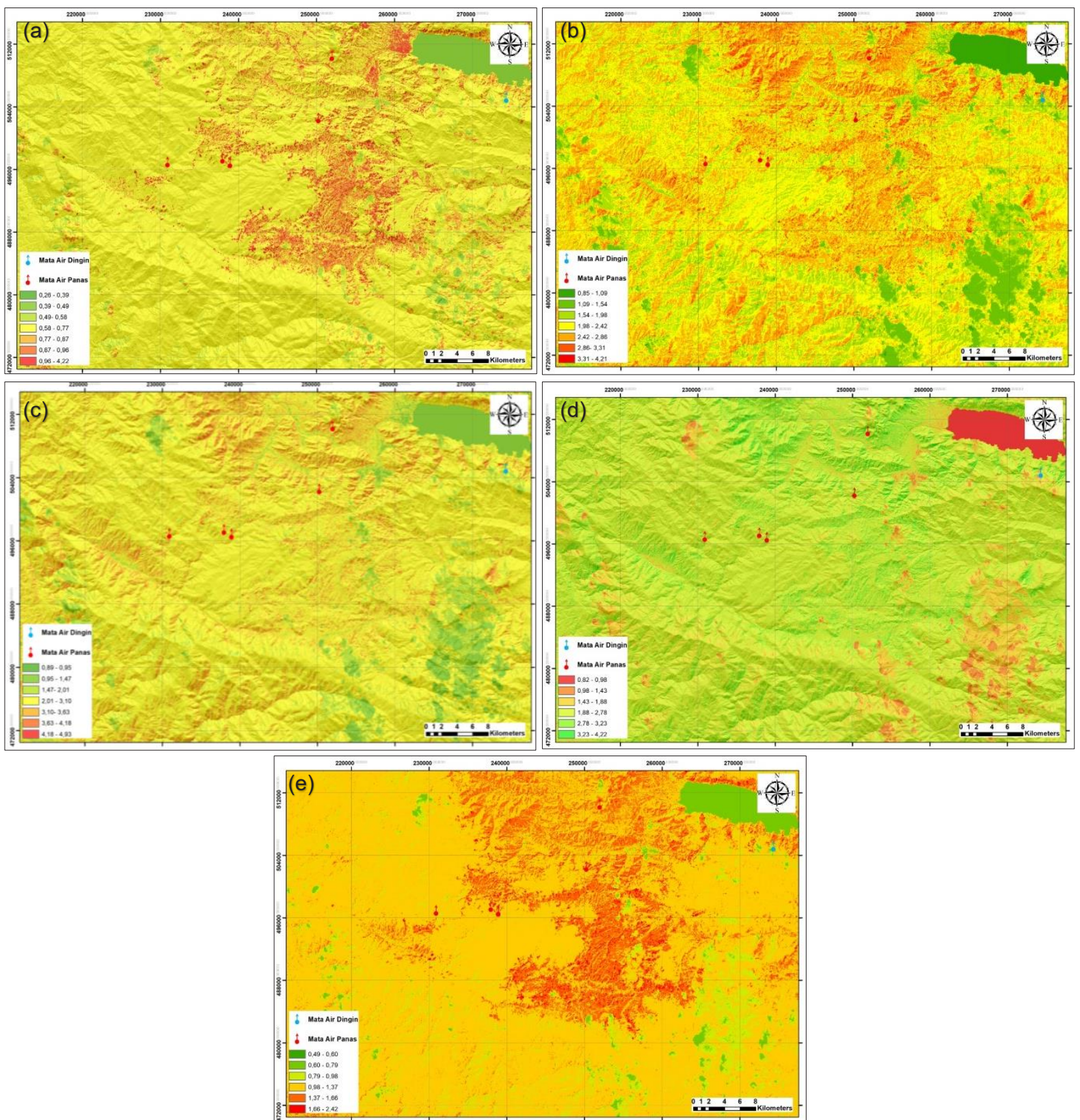

Gambar 10. Hasil Pengolahan Penerapan Metoda DPCA Untuk Mineral (a) Kuarsa; (b) Alunit; (c) Kaolinit; (d) Klorit; dan (e) Epidot

Hasil analisis FFD di daerah penelitian memperlihatkan bahwa zona outflow di daerah penelitian diperkirakan berada di sekitar manifestasi air panas yang berada di sebelah Barat Laut Gunung Telege. Lokasi manifestasi tersebut berada di tepi zona densitas kelurusan tinggi. Hasil ini serupa dengan studi yang dilakukan oleh Nugraha et al. (2018) untuk Area Prospek Ile Ange yang diperkirakan memiliki sistem panas bumi temperatur tinggi. Hasil yang kurang lebih sama diperoleh pada sistem panas bumi temperatur menengah di Marawa, Suwawa, Pulu (Suryantini dan Wibowo, 2010) dan Amohola (Nahli et al., 2016).

Sedangkan hasil analisis hubungan peta FFD dan perkiraan zona upflow pada area studi menghasilkan relasi negatif. Hal ini berbeda dengan hubungan positif seperti yang didapatkan dari studi Oktoberiman et al., (2014) di Gunung Slamet. Hasil yang sama, hubungan positif antara zona high 
density pada FFD map dengan zona upflow, juga terjadi pada studi yang dilakukan Soengkono (1999a, 1999b, 2000, 2002) di Daerah Te Kopia dan Mokai serta Rotorua yang termasuk Taupo Volcanic Zone (TVZ) yang dapat dikategorikan sebagai sistem panas bumi low terrain.

Dari analisis diatas, dapat diinterpretasikan bahwa zona upflow sendiri diperkirakan berada di antara zona outflow dan area heat source.

Berdasarkan analisis metoda penginderaan jauh terkait keberadaan sistem panas bumi di daerah penelitian, maka dapat direkomendasikan delineasi batas untuk kegiatan survei awal di daerah Kabupaten Aceh Tengah, seperti yang tampak pada gambar 11 (Kotak Warna Hitam).

\section{KESIMPULAN}

Penerapan Metoda FFD pada hasil interpretasi struktur geologi dari citra DEMNAS dapat digunakan untuk menentukan indikasi zona outflow sistem panas bumi. Sedangkan, integrasi Peta
Anomali LST dari Landsat 8 dan interpretasi circular feature dari citra DEMNAS dapat digunakan untuk menentukan indikasi sumber panas sistem panas bumi di daerah penelitian yang berada di Komplek Vulkanik Gunung Telege. Sementara itu, penerapan metoda DPCA pada Landsat 8 masih belum akurat mengingat adanya pencampuran (mixing) antar beberapa mineral dalam piksel yang sama atau tidak menunjukan nilai anomali.

Hasil interpretasi dan analisis citra DEMNAS dan Landsat-8 ini dapat menjadi salah satu alternatif yang murah untuk menentukan lokasi prospek panas bumi sebelum dilakukan observasi lapangan.

Untuk penelitian lebih lanjut terkait metoda penginderaan jauh di daerah penelitian, maka perlu digunakan citra satelit yang memiliki band dengan jendela spectral lebih kecil seperti citra multispectral (Citra Aster) atau hyperspectral (Citra Hyperion) dengan menggunakan metoda sub-piksel serta dilakukan validasi dengan data lapangan melalui kegiatan survei awal ke arah bagian barat dari Gunung Telege sebagai upaya pembuktian keberadaan sistem panas bumi di Daerah Aceh Tengah ini.

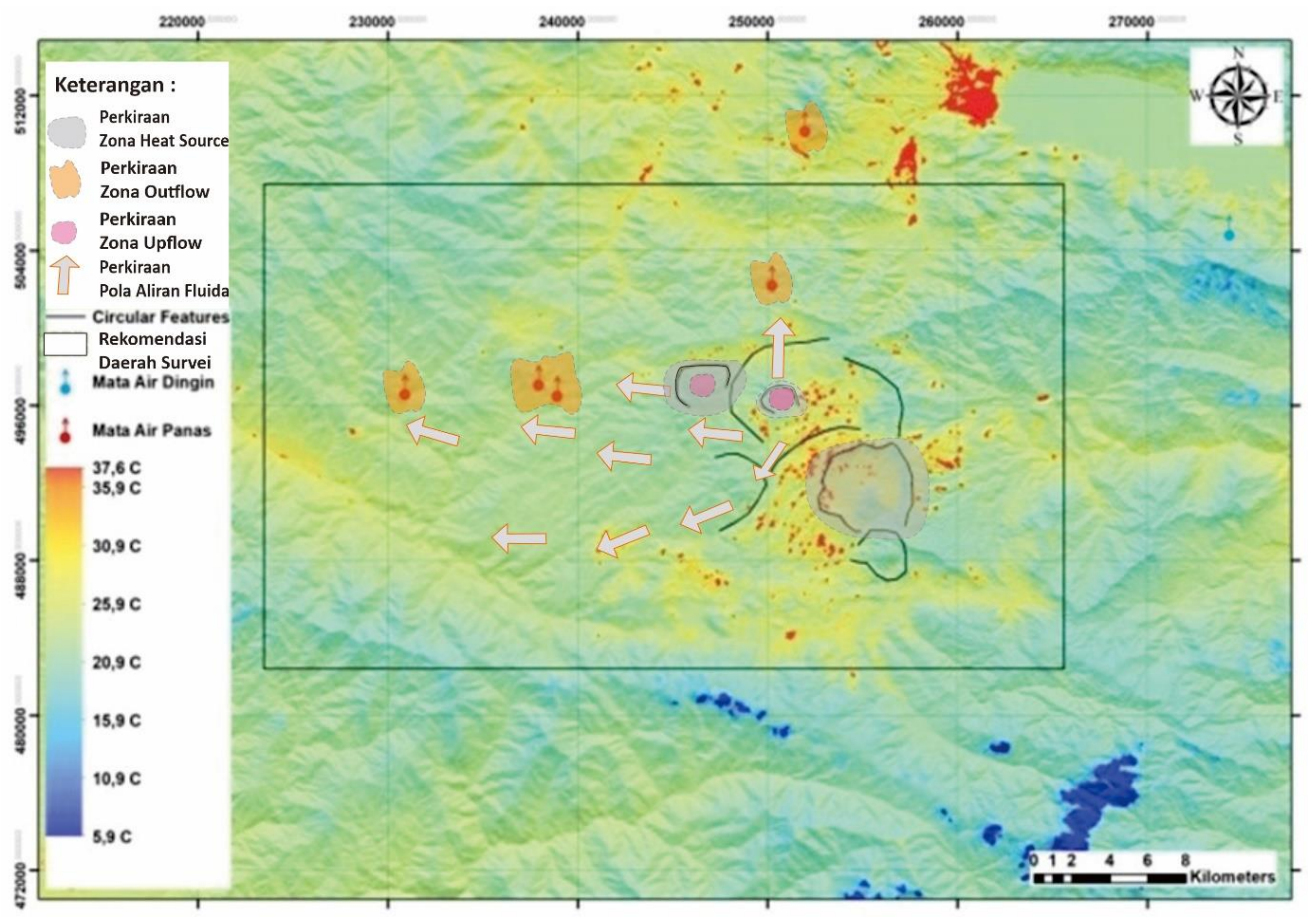

Gambar 11. Rekomendasi Daerah Untuk Pelaksanaan Survei Awal Lapangan 


\section{UCAPAN TERIMA KASIH}

Penulis ucapkan terima kasih kepada Koordinator Panas Bumi Pusat Sumber Daya Mineral Batubara dan Panas Bumi (PSDMBP) atas izin penggunaan data untuk penulisan makalah ini. Penulis juga mengucapkan terima kasih kepada tim editor yang telah memberikan koreksi serta saran dalam perbaikan makalah ini.

\section{DAFTAR PUSTAKA}

Anonim, 2014. Laporan Penugasan Survei Pendahuluan Panas Bumi Gunung Geureudong Kabupaten Aceh Tengah, Kabupaten Bener Meriah dan Kabupaten Aceh Utara - Provinsi Nangroe Aceh Darusallam. Tidak Dipublikasikan.

Avdan, U., dan Jovanovska, G., 2016. Algorithm for Automated Mapping of Land Surface Temperature Using Landsat 8 Satellite Data. Journal of Sensors, 2016.

Badan Informasi Geospasial, 2020. Seamless Digital Elevation Model (DEM) dan Batimetri Nasional. Diakses pada 3 September, 2020, Diakses dari https://tanahair.indonesia.go.id/dem nas/

Bivand, R. S., Pebesma, E., dan GomezRubio, V., 2013. Applied Spatial Data Analysis With $R$ (2 ed.). New York: Springer.

Cameron, N. R., Bennett, J.D., Bridge D.M., Clarke M.C.G., Djunuddin A., Ghazali S.A., Harahap H., Jeffery D.H., Kartawa W., Keats W., Ngabito H., Rocks N.M.S., Thompson S.J., 1983. Peta Geologi Lembar Takengon, Sumatera, Skala 1 : 250.000. Bandung: Pusat Penelitian dan Pengembangan Geologi.

Carnec, C. F., dan Hubert., 1999. Monitoring and Modeling Land Subsidence at The Cerro Prieto Geothermal Field, Baja California, Mexico, Using SAR Interferometry. Geophysical Research Letters, 26(9), 1211-1214.
ESRI, 2016. Hillshade Function, Diakses pada 10 September 2021, Diakses dari

https://desktop.arcgis.com/en/arcma $\mathrm{p} / 10.3 /$ manage-data/raster-andimages/hillshade-function.htm.

Fialko, Y. S., Mark., 2000. Deformation And Seismicity In The Coso Geothermal Area, Inyo County, California: Observations And Modeling Using Satellite Radar Interferometry. Journal of Geophysical Research: Solid Earth, 105(B9), 21781-21793.

Giordano, G., Pinton, A., Baez, P. C. W., Chiodi, A., Viramonte, J., Norini, G., dan Groppelli, G., 2013. Structural Control on Geothermal Circulation in the Cerro Tuzgle-Tocomar Geothermal Volcanic Area (Puna Plateau, Argentina). Journal of Volcanology and Geothermal Research, 249, 77-94.

Hakim, L., Ismail, N., dan Faisal., 2017. Kajian Awal Penentuan Daerah Prospek Panas Bumi di Gunung Bur Ni Telong Berdasarkan Analisis Data DEM SRTM dan Citra Landsat 8. Jurnal Rekayasa Elektrika, 13(3), 125-132.

Hall, R., 2002, Cenozoic Geological and Plate Tectonic Evolution of SE Asia and the SW Pacific: Computer Based Reconstruction, Model and Animation, Journal of Asian Earth Science p. $353-431$.

Hijmans, R. J., 2020. raster: Geographic Data Analysis and Modeling. Diakses dari https://CRAN.Rproject.org/package=raster

Jónsson, S., Adam, N., dan Björnsson, H., 1998. Effects of Subglacial Geothermal Activity Observed by Satellite Radar Interferometry. Geophysical Research Letters, 25(7), 1059-1062.

Lê, S., Josse, J., dan Husson, F., 2008. FactoMineR: A Package for Multivariate Analysis. Journal of Statistical Software, 25(1), 1-18. 
Nahli, K., Mulyana, F., Tsani, G. E., Alwan, M. A., Darojat, M. H., dan Hendrawan, R. N. (2016). Identifying Non-Volcanic Geothermal Potential in Amohola, Southeast Sulawesi Province, by Applying the Fault and Fracture Density (FFD) Method. IOP Conference Series: Earth and Environmental Science, 42, 012015.

NASA, 2013. Landsat Data Continuity Mission Continuously Observing Your World., Diakses pada 1 November 2020, Diakses dari https://landsat.gsfc.nasa.gov/sites/la ndsat/files/2012/12/LDCM_Brochure Dec2012.pdf

Nugraha, H. S., Shiddiq, A. M. I., Agustin, F., dan Surmayadi, M., 2018. Comparison of Application Faults and FractureDensity (FFD) Method using SRTM 90-m, SRTM 30-m, and Aster GDEM 30-m for Geothermal Exploration: a Case of lle Ange Prospect., 7th ITB International Geothermal Workshop 2018, Bandung.

Oktoberiman, Ramadhan, D.A., Rizki, F., dan Tawakal, R.(2014). Identification of Geothermal Potential Based on Fault Fracture Density (FFD), Geological Mapping and Geochemical Analysis, Case Study: Bantarkawung, Brebes, Central Java., the New, Renewable Energy and Energy Conservation Conference and Exhibition - The 3rd Indonesia EBTKE-ConEx, Jakarta.

R Core Team (2013). R: A Language and Environment for Statistical Computing. $\mathrm{R}$ Foundation for Statistical Computing, Vienna, Austria., Diakses pada 1 November,2020,Diakses dari http://www.R-project.org/.
Salamba, K. E., Hede, A. N. H., dan Heriawan, M. N., 2019. Identification of Alteration Zones using a Landsat 8 Image of Densely Vegetated Areas of the Wayang Windu Geothermal Field, West Java, Indonesia. The IOP Conference Series: Earth and Environmental Science.

Soengkono, S., 1999a. Analysis of Digital Topographic Data for Exploration and Assessment of Geothermal System., 21st New Zealand Geothermal Workshop.

Soengkono, S., 1999b. TeKopia Geothermal System (New Zealand) the Relationship between Its Structure and Extent. Geothermics, 28(6), 767-784.

Soengkono, S., 2000. Assessment of Faults and Fracture sat the Mokai Geothermal Field, Taupo Volcanic Zone, New Zealand., World GeothermalCongress.

Soengkono, S., 2002. Assessment of Topographic Lineaments across Rotorua Geothermal Field., 24th New Zealand Geothermal Workshop.

Suryantini, dan Wibowo, H. H., 2010. Application of Fault and Fracture Density (FFD) Method for Geothermal Exploration in NonVolcanic Geothermal System; a Case Study in Sulawesi Indonesia. Jurnal Geoaplika, 5(1), 027-037.

USGS. (2020). Earth Explorer., Diakses pada 3 September, 2020, dari https://earthexplorer.usgs.gov/

Van der Meer, F., Hecker, C., van Ruitenbeek, F., van derWerff, $H_{\text {., }}$, deWijkerslooth, C., dan Wechsler, C., 2014. Geologic Remote Sensing for Geothermal Exploration: A Review. International Journal of Applied Earth Observation and Geoinformation, 33, 255-269.

\begin{tabular}{|ll|}
\hline Diterima & $: 8$ Mei 2021 \\
Direvisi & $:$ 4 Juni 2021 \\
Disetujui & $: 30$ November 2021 \\
\hline
\end{tabular}

